\title{
An Investigation of the Constraints in Subtitling the Conversations: On the Role of Cultural Effects on Variation
}

\author{
Faranak Nemani
}

(Postgraduate Researcher, Islamic Azad University, Najafabad Branch). Email: faranaknemani@yahoo.com

\section{Abbass Eslami Rasekh}

(Asso Prof. University of Isfahan). abbasseslamirasekh@yahoo.com

Doi:10.5901/jesr.2013.v3n2p97

\begin{abstract}
Translating cultural elements has always proved a demanding task as the items of vocabulary carry both specific semantic and social meanings in the culture of the source Persian language different from the target English. The difficulty increases when in subtitling other constraints make the task even more difficult such as time limit and the space within which the message is transferred into the target English. Taking this fact into account, the present study aims to compare the Persian expressions of the movie called ASeparation with the English subtitles to discover the degree of translatability with the same functional effect. The procedures involved first, transcribing the conversations between the characters of the movie, and then the subtitler's choices of English equivalent counterparts were examined for discovering how efficiently the functional effects could be displayed comparably in the target English. In addition to the data gathered, further natural data in the form of interviews, observations, and recordings of various sorts were collected and examined to display how the culture of the SL Persian differs from the TL English. The findings revealed that a considerable number of functions employed in the Persian speakers' conversations were unique to the culture; a good number of utterances would have lost their true functional effects when they were translated for the English audiences as our comparisons revealed. The effect of power on speech variation is comparably more observable in Persian source speech compared with English as the target speech norms, although both languages display the effect in varying levels.
\end{abstract}

Key words: Translation, Subtitle, Culture, Source Language, Target Language.

\section{Introduction}

Translation is defined as an attempt to replace a statement in one language by the same statement in another (Newmark, 1988a, p. 7); and in Nabokov's sense as quoted in Newmark (1988a), "rendering, as closely as the associative and syntactical capacities of another language allows, the exact contextual meaning of the original" (p. 11). According to these definitions, some sources of loss can be identified. The first source as Newmark (1988a) suggests is the loss of meaning, since the translator's language can only be approximate not exactly the same, "if the text describes a situation which has elements peculiar to the natural environment, institutions and culture of its language area, there is an inevitable loss of meaning" (p. 7). The second source of loss is related to the personal use of language by the author that is related to his/her style, "...the individual uses of language of the text-writer and the translator do not coincide" (Newmark, 1988a, p. 8). He believes that everybody has lexical if not grammatical idiosyncrasies, and attaches new meanings to a few words. The transfer of a message is constrained by several factors; therefore, it is a widespread claim that one never expects translation in the full sense; there is always a degree of relativity involved which could not be resolved however skillful the translator is.

During the twentieth century, a new register of speech emerged that was to be translated,as the result of the arrival of film industry and the invention of sound films in 1927. That time translation was used to convey the 
spoken dialogue of source language (SL) film to the target language (TL) of the audience. This new type of translation was called Audio Visual Translation (AVT). AVT is conventionally taxonomised into "subtitling" and "dubbing" which are the main forms of language transfer in different media. The first one which is the focus of this paper is defined as "supplementing the original voice soundtrack by adding written text on screen" and the second one is "replacing the original voice soundtrack with another in another language" (O'Connell, 2000, p. 169). This aspect of translation provides the analyst with new dimensions in translation studies.

The subtitle is an abbreviated version of the dialogue, which is projected on the screen. It is considered a complex and challenging variant of theatrical translation. Gottlieb (2005) states that wheneverconditions such as affordability, dialog authenticity, knowledge of foreign language and reading skills required for audiovisual translation,allow subtitling is the obvious solution. However, limitations are obviously mentioned which are related to the fact that interlingual subtitles reduce the original script by simplifying it (Pavesi, 2002), due to the rigid space and time constraints that this translation medium imposes. In addition, the transformation from the oral script to the written subtitles also contributes to the quality of the language, which becomes more formal and neat, almost devoid of the many sociolinguistic and pragmatic markers that give spoken language its natural flavor (Bussi Parmiggiani, 2002, p. 180).

Given these limitations, it has been observed that some elements are bound to be deleted more than others. Reduction strategies mainly apply to not only the redundancies in the spoken text, but also to modulating and pragmatic markers, which are considered less important for conveying the conceptual meaning of the original. Yet, as has appropriately been shown (Kovačič, 1996; Blini \& Matte Bon, 1996; Bussi Parmiggiani, 2002), deletions of these aspects "may create a substantially different interpersonal dynamics from that intended" (Hatim\& Mason, 2000, P. 438). Blini and Matte Bon (1996) have thoroughly demonstrated that modifying or eliminating such markers in the written subtitles corrupts the sociolinguistic and pragmatic meanings conveyed by the original. A compromise should therefore be aimed at, in which "the illocutionary aspect of the text should therefore be privileged by trying to reproduce the same speech acts in the target language on the basis of a careful analysis of the pragma-linguistic elements" (Blini\& Matte Bon, 1996: 328; my translation).

Culture-bound terms or as some call culture-specific items refer to those items which have either no equivalents or different positions in target reader's cultural system, thus causing difficulties in the translation of their functions from the source text into target text. According to Hatim and Mason (2000, pp. 223-4) "it is certainly true that in recent years the translator has increasingly come to be seen as a cultural mediator rather than a mere linguistic broker. It is also true that, in any form of translation, translators tend to apply a general strategy that will favor either an SL-oriented approach, or a TL-oriented approach."

Newmark (1988, p.78) maintains that translation problems caused by culture-specific words arise due to the fact that they are intrinsically and uniquely bound to the culture concerned and, therefore, are related to the context of a cultural tradition. There are many ways to categorize culture-specific items; for instance, Newmark (1988) points out five areas that cultural items may come from: (1) ecology (flora, fauna, winds, etc), (2) material culture (artifacts food clothes houses and towns, transport), (3) social culture (work and leisure), (4) organizations, customs, ideas (political, social, legal, religion or artistic), and (5) gestures and habits.

The purpose of this study is to compare the source Persian utterances of the movie called ASeparation with the English subtitles to discover the degree of translatability of the utterances with the same functional effect.Additional data gathered through observations, recordings, and from different media are discussed in a qualitative style to demonstrate the significant the role of social variables in creating social variation and untranslatability of a significant proportion of the data given the functional effects.

\section{Methodology}

\subsection{Participants}

The work presented in this article is not empirical by nature; however, six major characters in a fictional world of a movie provide us with the data of the study. The participants could be said to include the characters of the movie whose speeches are recorded and analyzed for the purpose of the study. In order to compare the Persian utterances with the English subtitles to discover the degree of translatability of the utterances with the same 
functional effect the main characters of the popular Iranian movie, known as A Separation, were selected and their conversations in various contexts were recorded and transcribed.

\subsection{Instruments}

To collect data, we could employ such instruments as DCT, but the limitations of this type of data have been shown; data gathered in this way will certainly be devoid of the rich characteristics of transcriptions of original speech by characters in various contextual settings. The world created by the movie could be claimed to enjoy some qualities which DCT is most probably deprived of. Could we call the movie, a fictional world representing the real world of today Iran, instrumentation of a kind? We leave this to the readers who may judge how we can ignore the limitations of the subtitling and stick to the importance of how effective natural data could be in a context which is not limited to one or a couple of conversation pairs; it is a collection of contexts which displays various registers of speech in a fair degree of length. The Iranian movie called $A$ separation was, therefore, viewed as the instrumentation employed for collecting the major proportion of our data. The data gathered from the English subtitles of the Persian speeches of six characters acting naturally in a 2011 Iranian drama film written and directed by Asghar farhadi (2011). This film gained world-wide popularity when it succeeded in winning the Oscar, the Academy Award for best foreign language film in 2012.

In order for readers who may not have watched the movie, the themeis provided below.

\subsection{The Oscar Winning Movie: A Separation: A Brief Review of the Plot}

"A Separation," a tightly structured, emotionally astute new film from Iran, begins with a couple in distress, arguing in front of a judge. (1) Simin (wife) who works as an English teacher wants to leave her husband (2)Nader, a bank employee, because he won't go along with her desire to emigrate in search of better opportunities for their 11-year-old daughter, (3)Termeh. In response to Simin's urging for immigration, Nader insists on staying in Tehran; his main reason is to take care of his frail and elderly father, who suffers from Alzheimer and needs constant attention. Because Nader (husband) refuses to agree neither to leave the country nor to give the legally required permission for his daughter to leave the country with the mother, Simin (wife), who is upset, leaves Nader's house to live with her parents. And to do the housework, Nader hires a devout young woman (4)Razieh, to help look after his father for a day by day salary. Razieh, whose husband is very religious with lots of prejudice against her being left in a stranger's house, has not dared tell her out-of-work husband, (5) Hodjat, about her catering job in Nader's, which is a stranger's house. As for her pregnancy, Razieh has not mentioned anything about it, neither to her husband nor to Nader; therefore, Nader does not know that she is pregnant. One day when Nader and Razieh scuffle as a result of Nader's finding out his father had been left unattended due to Razieh's leaving the house; she accuses him of causing her subsequent miscarriage as she was pushed down the stairs. And Nader is consequently sued and charged with murder by the (6) Judge who is present in a good number of the conversations. Nader is back in court, embroiled in long arguments with Razieh and her husband, Hojat, an unemployed shoemaker laden with debt and seething with resentment, humiliation and angry piety. In Hodjat's eyes Nader and Simin are part of corrupt and entitled elite, arrogant and irreligious and full of contempt for an ordinary working man like him.

The conflict could be judged as clash between social classes: one with nothing to lose, the other a social group with enough wealth to pay for the dead child. The scenery plays out as a tragedy in which religion and the class system is as much on trial as the main characters who belong to at least two distinct separate groups.

\subsection{Procedure}

The Procedures for obtaining required information were simple: Closely examining the movie data in order to get, in addition to the overall idea, to find instances of the Persian culture-bound terms as well as the entire expressions which show differences resulting from the effect of the social variables or differences across the two culture in the sense that the functional message is carried. The step by step examination of conversations, in terms of pairs and individually, involved identifying, categorizing, and explaining differences in the phrases used which carried a function, and also the linguistic concepts which were judged to be impossible to carry into the 
English target culture; and ultimately utterances which were functionally very difficult or impossible to be translated into English target language. The focus for comparison and the views for all the strategies of translating was on the transcripts and on the English subtitles of this film.

\section{Results: Functionally Difficult Units of Communication}

Table 1 presents a list of the utterances which could not properly be translated into English. The table shows not only utterances impossible to translate with the same functional effect, but also lists concepts which could not be discussed and thought about in the target culture. The concept of wife for example, in English is one reference form; however, in Persian wife, which is a proper suitable English expression, changes when translated into Persian: namous is a referring word which could not be understood in English. Another referring form is zan which is equivalent to woman in English; however, there are huge differences in the connotations of Persian zan. So, wife in Engish has three equivalents if we leave aside terms which are not in used in modern cities today: hamsar ,zan, and namoos. The three show how in Persian one's wife is his sacred possession not to be touched or talked to (namoos)and not to be addressed by her first name (the social meaning of zan). The most recent is hamsar with a social meaning which shows equality in the sense that it refers to one's partner, either wife or husband. Before the Islamic Revolution, one's wife would be referred to by names such as zaifeh (one who is weak and female; this referring expression is used in remote rural areas, but not in cities).

The variation of swearing in Persian makes it completely different from English: in Persian lots of living sacred and non-living figures could be reference terms for swearing, unlike English which is limited to one's life and to God. Persian is very rich in swearing, in addition to the God's name, a) the messenger of Islam and the holly book of Moslems Quoran, b) sacred infallible Imams, c) their blood relatives who have had a historical significance (there are thousands of resting places and tombs belonging to relatives of Imams holly to the religious people who swear to them), d) to death or life of one's mother, father, sister, daughter, son, brother, e) to the beard of the speaker and the addressee (being a sign of manlihood), f) to swear to one's namoos (wife in English, who is so sacred that one swears to): these all make an independent separate research for detailed examination.

As indications of differences of the world a Persian speaker lives in compared with the world of an English, the use of honorific terms is a reflection of how Iranian society is a hierarchy of social power levels, more specifically political and religious power groups making a hierarchy; display of power is not reflected only by pronominal address terms, but also in verbal endings and choice of the verbs which are divided into those which are honorific and those which are non-honorific. Together, reference by pronominal expressions, titles, and use of endings signify indicators of powerforming a great list of functional expressions. So, the other issue of functional difference reflected in the use of referring expressions, titles, and endings of the verbs, is type of mitigations in Persian which could be different from English. These expressions could be classified under the heading of honorification of verbs and address terms. Examine the following most frequent expressions in Persian showing the addressee is more powerful:

Tashrif bi-avar-id (honor conjunctive be- bring- id $\left.\left(2^{\text {nd }} p l\right)\right)=$ En. Come. be-farma-yid (conjunctive be- order- $2^{\text {nd }}$ plural) = En. (substitute for) eat, come, get in, go out, enter, drink, etc..

jesart-an, arz-kard-am (boldness-(adv marker) petition-do- (past $\left.1^{\text {st }}\right)=$ En. I am forgivably dare to say. Mohabbatkon-id (Affection do- $\left(2^{\text {nd }} p l\right)=$ En. Please

The effects of cultural norms are presented in the pieces of conversations marked as examples sequentially ordered. As shown in examples below, one can observed how in Persian verbs are chosen for varying politeness levels under the effect of power of the addressee which arises not from mere class which is determined by a combination of five determiners, political power above occupation as one determiner, education, religious influence, parents, area of residence and wealth; among them, political and religious power could function as a class raising factor more effectively. The effect of political power may be so decisive in one's class that with loss of the political power, one's class is significantly demoted. As extract 1 shows, family is a substitute for wife, as it is polite and in agreement with the social norms of the social class group who use it. The speaker represents a low social class, who is a shoe maker and wishes to work in a house as a house worker: 
Persian 1: $H$ to $N$ : Khanevade tashrifna-dar-and?

Transliteration (hereafter TL): $H$ to $N$ : Family (a substitute for wife honor na- (Negative marker) have( $3^{\text {rd }}$ plural)?

English1: $H$ to $N$ : Will the family not be there?

$$
\text { حتبت به نادر: خانواده تشريف ندارند؟ }
$$

Persian 2: $H$ to N: Jesaratan in karke mi-farma-yid ba 300 tooman ye-khord-e kamnist?

$T L: H$ to N: Regardless of fear this work that you order $2^{\text {nd }}$ person plural with 300 Toman one eaten little negative be $3 r d$ singular?

English 2: $H$ to $N$ : Excuse me, but 300,000 for this job, isn't it too little?

$$
\text { حجت به نادر: جسارتاً اينكاركه ميفرماييد با } 300 \text { يه خورده كم نيست؟ }
$$

Example two shows how the speaker of the low working class wishes to challenge the offer made to him. Mitigation is not equivalent in English: Excuse me is even not natural to say in such a context in English. One does not have to apologize for asking for a higher salary. Making it indirect, by saying its being little, is another strategy of being polite in the sight of a more powerful employer. The Persian version reads: this amount is a little less than expected, while the English version is different: isn't it too little; which implies way higher expectations for a wage, in contrast with the Persian version which tries to underline a little less than it should be.The functional effect vary in several ways: a) mitigation which is translated into English as excuse me, b) use of an honorific verb: mi-farma-yid (pres, order- $\left(2^{\text {nd }} \mathrm{pl}\right)$, and $\mathrm{c}$ ) emphasis on being indirect and a bit less which in English has changed to too little signifying a semantic change leading to a functional purpose.

Persian 3: $N$ to R: Khanoomoonroye sag-e man-o dar-i mi-yar-l bala-ha

TL: $N$ to R: (Miss, Mrs, Ms,Lady) that (Emphatic marker)face-of dog-i (adj marker)-am (1 ${ }^{\text {st }}$ sing)- ro (obj marker) $d A r-i\left(2^{\text {nd }}\right.$ sing) $m i$ - (present simple marker) bring-(present)-i ( $2^{\text {nd }}$ singular) up- ha (emph marker).

English 3: Ma'am, you're really getting me angry!

$$
\text { نادر به راضيه: خانم اون روى سخمنُ دارى ميارى بالاهـا }
$$

The effect of power is manifested in 3 in which the man says to a woman worker: use of) emphasis markers (that face, ha meaning emphasis); a more similar translation is: Ms, you are bring up my other dog like temper-emphasis. The emphasis in English is really which is much less effective in showing anger. A substitute for angry could normally be asabani; in Persian it is my dogish face being brought up. The two features, emphasis doubly made, choosing a substitute to show how powerful the speaker is, my dog-like face could not have been conveyed into English; and these can show how power changes the variety of speech.

The unique characteristics of Persian which illustrate the social structure, how publically oriented it is, and how power-oriented, are partly illustrated in 4:

Persian 4: Sister in law to $R$ : to R: Abero- riz-i na-kon to roemam Hossein

$T L$ : SIL to R: Water- puring-na (Neg marker) -do (imperative $2^{\text {nd }}$ singular) you ( $2^{\text {nd }}$ singular) ro (object marker) imam hossein (one of the fourteen infallible holly Infallables).

English 4: Sister in law to R: Don't make us look bad, I beg you.

$$
\text { خوراهر شوهر به راضيه: آبروريزى نكن تو رو امام حسين }
$$

There is a term in Persian which points to public face; it is different the well-known positive and negative face. It signifies that what you say in private don't say in public. The request is for Razieh to not show rudeness, in Persian it is pouring water; this expression is the emphatic word substitute for be polite; don't be impolite. To make her comply, she uses swearing, to the name of the third Shieh Imam, called Imam Hossein, who is sacred for the believers. Swearing of this type is more frequently used by the lower class less privileged class of society. The English version is meaningful only as partially equivalent to the culture of its use in Persian. A lot of social 
meaning is lost due to the type of swearing which does not exist in English. The subtitle omits the part, as it is not easy to present a translation in so short a space and time.

The extracts above show how the social meaning and the functional effects of the expressions and referential devices are not possible to convey in English. The fact is that it is clearly obvious that the translation of the expressions above is either impossible or very difficult with a lot of functional loss of effect. Examples such as these are found in plenty, a sample of which is provided in table 1 for readers to examine and judge. The answer to the transferability of the functional effect is given when the examples are observed. Whatever strategy the translator chooses, there will still be loss in conveying the functional effect cross-culturally. The list of expressions used in the conversations indicated four categories which signified the role of power in conversations. Such categories were omitted, changed, or translated with much less effect. Below, we will discuss examples of a) use of honorifics in the pronouns as well as verbs which by style are used for showing extreme politeness; b) use of mitigation in various forms different from English; c) swearing which indicate the emphasis in Persian, either for being right, claiming the truth, or requesting with compliance, and d) use of culture bound expressions, words, and idioms which were among the difficult concepts.

\subsection{Honorific Aspects}

The use of respectful verbs as well as pronouns is an indication of acknowledging the addressee's power or superiority; which is brought about either by political power, judicial power, or as a result of the features of context. It is important not to confuse power with solidarity in Persian. Solidarity is brought by age of the citizen, by knowledge, by being attached to religious and ethical values; their effect on speech variation could be the same as power. Indeed markers of acknowledging power are also markers of high solidarity in relations; marker of high social status are also markers of social power; the difference is that one is respect by influence but the latter is respect by being a member of the elite and having connections. While social solidarity and power are marked in opposite ways by languages, social class and status are marked by the same set of markers. Honorific pronouns are used for showing one's power over the speaker; or social distance between them. In example 5, social distance has caused a degree of politeness which is demonstrated by honorific pronouns: I saw you (pl), your (pl) husband ... The distinction does not exist in English, therefore lost in translation.

English 5: Ms Ghahrayi to S: It's good I saw you here... What happened? Is it true that your husband...? Persian 5: MS Ghahrayi to S: Khoob shod didam-e-toon. Chi shod-e? Vagheyiatdar-e inkeshohar-e-toon...

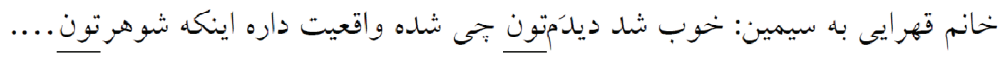

The role of solidarity mixed with power is demonstrated in 6 in which a lady is speaking with her neighbor who is a man, Nader:

English 6: MsGhahrayi to N: I'm fine, thanks, you? Are you fine?

Persian 6: MS Gh to N: Khoob-am mamnoonazmohabat-e-toon, shoma-khoob-id, Khastena-bashid.

$$
\text { خانم قهر ايى به نادر: خوبم ممنون از هحبت تون ، شما خوبيد ، خسته نباثيد. }
$$

The use of honorific pronouns is specific second and third person referents who are singular. The respectful expressions are plural showing the salience in the eyes of the speaker. The use of mitigation makes Persian different from English. Both 5 and 6 are viewed to be interactional functions of speech; they are communicating feelings rather than information. Interactional function embodies a significant proportion of Persian. The speakers are talking about how each other feel and how things are for them. Such a type of interactional speech is found in greater abundance in Persian than in English. The idiomatic utterance: don't be tired, which is part of the interactional conversation could not be translated into English. 


\subsection{Swearing types}

Swearing in Persian is a rather different function in speech. Its use indicate a lot of social information: that the speaker is a religious one, working class, limited in terms of access to resources, and not highly educated. The low social class believes that miracles might happen if you just name the holly persons; and this is partially how speech is filled with swearing expressions. The extracts below show how types of swearing are used for various functions. In 7, it has the function of bringing compliance with a request, in 8 it is used to beg, in 9 the woman is displaying at most lack of power; it is unique to Persian norms that a judge could be forced to comply if you swear to make your request. In $10, \mathrm{H}$, who is the low working class speaker, is taking away the trustworthiness of Nader by rejecting his belief in God and the Messenger of Islam. Finally in $11, \mathrm{~N}$ who represents a fairly higher class is challenging the claim by saying in an ironic way that God and the Messenger don't belong to them only.

English 7: $R$ to $S$ : No please. I beg you not to take these words outside here.

Persian 7: $R$ to $S$ : Na to roGhoran. Man ghasam-e-toon dad-am in harf-a az in jabiroonna-re.

$$
\text { راضيه به سيمهين: نه ترو قر آن. من قـمهتون دادم اين حرفا از اينجا بيرون نره . }
$$

English 8: $R$ to J: I'm begging, please don't call anyone

Persian 8: $R$ to J: Agha to roGhoran-e majidzangna-zan.

$$
\text { راضيه به قاضى: آقا تر قرآن مجيد زنخ نزن }
$$

English 9: R to J: Judge, I beg you. Give me one second, Sir. Sir, he's just under a lot of stress, I swear. Persian 9: $R$ to J: Haj agha to roGhoran, to roAbolfazl, Agha ye lahze be man ejazebedeshoma. Haj agha beGhoran.....

$$
\text { راضيه به قاضى: حاج آقا تورُ قرآن ، تورُ بالفضل ، آقا يك لحظه به من اجازه بده شما. حاج آقا به قر آن.... }
$$

English 10: $H$ to $N$ : As if you believe in God!

Persian 10: $H$ to $N$ : cheghadramshomaahlekhodavapeyghambar-id?

$$
\text { حجت به نادر: جقدرم شما اهل خحدا و بيغمبريد ؟ }
$$

English 11: No, God is just for you people.

Persian 11: N to H: Na khodavapeyghambarfaghat mal-e shoma ha-st.

\subsection{Mitigation}

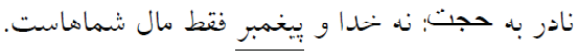

Persian speech is full of mitigation the same way it is full of swearing and full of interactional functions. Real communication happens in smaller proportions compared with English as Persian speakers believe and public face called Aberu (water of face) in public is important. It is normal for a parent to advise the child not to say anything rude, eat much, etc in the party; while in private it is OK. The concept of Aberuagrees with use of mitigation in the sense that the more mitigation one finds in speech, the more the speaker displays saving the public face.

The variety of mitigation devices and expressions is much greater in Persian than English. Such mitigation devices used for thanking, mercy, and be kind, in 12 and 13, affection do, give permission, in 14, these are examples found in the limits of the movie. A great deal of strategies of mitigation with functions different could be found in Persian. As you may have noticed already, mitigation is not only used for showing politeness, it is used also for other functions such as begging, getting compliance, praising, acknowledging the power, and showing respect which is the primary function. 
English 12: MsGhahrayi to N: I'm fine, thanks, you? Are you fine?

Persian 12: MS Gh to N: Khoob-am mamnoon az mohabat-e-toon, shoma-khoob-id, Khastena-bashid.

$$
\text { نادر به خواهوشوهر: مرسى خانوم. خانوم محبت كنيد دخترمم صدا كنيد. }
$$

English 13: $N$ to R: Please lock the door behind me

Persian13: $N$ to R: Bashe in dar-am mohabbatkon-inposht-e man ghoflkon-id.

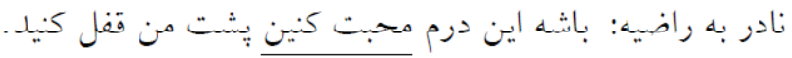

English 14: $\mathrm{N}$ to $\mathrm{H}$ : Look, come with me so I can explain.

Persian 14: $\mathrm{N}$ to $\mathrm{H}$ : Tashrifbiyar-id man behet-oontozihbedam

\subsection{Culture bound expressions}

$$
\text { نادر به حجت: ببينيد تشريف بياريد من بهتون توضيح بدم. }
$$

It is a relativistic issue to speak about cultural elements. All types of idioms, some metaphors, and proverbs could be rooted in a nation's history and thus be culture bound. In the area of bound elements, we did identify simple concepts, phrases forming a propositional meaning, and complete utterances representing a culturally unique value.

English 15: Ms Ghahrayi to N: I'm fine, thanks, you? Are you fine?

Persian 15: MS Gh to N: Khoob-am mamnoon az mohabat-e-toon, shoma-khoob-id, Khaste na-bashid.

$$
\text { خانم وقهرايى به نادر: خوبـم ممنون از محبت تون ، شما خوبيد ، خسته نباثيد. }
$$

English 16: $H$ to N: You asshole pushed her that she slipped.

Persian 16: $H$ to $N$ : toye bi-sharaf hol-esh dadi ke liz khord-e, oftad-e.

$$
\text { حجت به نادر: توى بيشرف هلش دادى كه ليز خورده ، افتاده. }
$$

English 17: J to Soldier: Please, open that window.

Persian 17: J to Soldier: Agha bi zahmat panjere ro baz konid.

$$
\text { قاضى به سرباز: آقا بى زحمت ينجره رو باز كنيد }
$$

English 18: $N$ to $R$ : Ma'am, you're really getting me angry! Persian 18: $N$ to $R$ : Khanoom oon rooye sage man-o dari miyari bala-ha

English 19: N to S: What the hell are you talking about?

$$
\text { نادر به راضيه: خانم اون روى سخع_من دارى ميارى بالاها. }
$$

Persian 19: $N$ to S: Chera mozahraf migi? Mage aslan bahs-e pool-e

$$
\text { نادربه سيمين: جرا مزخرف ميحى محة اصلاً بحث يول }
$$

English 20: $\mathrm{H}$ to J: Sir, if they don't care about honor, I care.

Persian 20: $H$ to J: Haj agha age namoos vase inha mohem nist vase man mohem-e.

$$
\text { حجت به قاضى: حاج آقا اكه ناموس واسه اينها مهم نيست واسه من مهمه. }
$$

English 21: $N$ to H: Thank you very much! Our agreement was to tie this poor man, and do your own job? Persian 21: $N$ to H: Dast-e shoma dard na-kone. Har rooz gharar-e ma in bood, dast-e in piremard-e bizaboon-o be-band-i beri sare kar-e khod-et.

$$
\text { نادر به حجت: دست شما درد نكنه . هو روز قرار ما اين بود. دست اين بيرمرد بح زبونوبيندى و برى سر كار خودت. }
$$




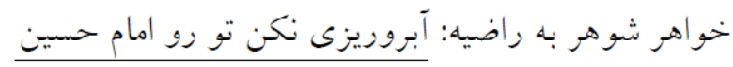

The culturally bound elements include a single concept such as namous signifying the significance of one's wife, to khast-eh na-bAsh-id.(tired-pp negative mark-ba (subjun) sh (be)-id ( $2^{\text {nd }} p l$ ) which equals don't be tired. This idiomatic expression is one of the most frequently used interactional expressions in Persian; each person might say it tens of times. However, the expression is absent from the English culture. In 16, you, without-honor is used to show extreme resentment; the speaker uses it to sound he is ready for a physical fight; now compare with the English equivalent translation. In $17, \mathrm{Mr}$, without-trouble is an expression which is most frequent and so colloquial and mentioned all the time to show one's thankfulness, as mitigation for asking for a favor, request, etc. The culturally bound expression dog-like face is used by one who is void of social ranking; however, it is used by one who is a member of the higher social class. This is the explanation why in Persian, there is no guarantee that social class corresponds with politeness; it is possible for one to get anger and enjoy unequal power and say impolite things. The utterance in 18 is a threat, full of derogatory expressions, lack of minimum respect; the addressee is defenseless in a complete sense. This is when in private, not in public, one shows anger in a rude style of speech. In 19, mozakhraf (nonsense, sill talk, rubbish) indicates the power attached to $\mathrm{N}$ compared with Simin. The unequal power may lead to the use of the expression; this style could not have been used in the sight of the judge; but at home, it would be OK. In 20, nAmous is a substitute for wife with connotations which never exist in English. The referential devices used for referring to women include, rarely first name, it is taboo to use the first name of one's wife in public, instead, use the name of the oldest son; or if you are from a modern category, you would use the family name, woman, partner, the weak one, the title Ms (lady) for public, and a set of titles which are used by people to refer to a female professional, such as Doctor, but not by her husband. In 21, ironic mood is used by Nader, may you hand never ache, was it our agreement that you tie the old man's hand to bed and leave him to go to your own work? It is clear that an English speaker never makes any sense of may your hand never ache; the explanation is that all languages are relatively autonomous in dividing meaning and intensions into words and expressions. It is completely relativistic. One can never make sure one has been able to do the translation job completely correctly.

\section{Conclusion}

The data examined in the above sections presented the frequent use of a) mitigation, b) honorification, c) swearing, and d) culture bound expressions as displayed by extracts. The four major speech functions are agreeable to the contexts of the story, mostly conflicts and struggle of powerless with powerful. In Persian, it is the power which is obviously signified by various linguistic markers; and the use of the four functions was frequent as the context included ones of conflict. In sum, Persian is a public oriented, power oriented society in which power is the more influential factor in speech variation. Persian class does not guarantee speech style; to be polite does not indicate to be of a higher class. And class is related to political power more than wealth, political power that has the approval of the religious elite has the most influence. In Persian, a society which has undergone a revolution a type of socialism is governing the life style. The wealth of an individual does not bring class necessarily as much as political power endorsed by the religious elite brings power attributed to class. In the culture, one who is in the position of connection to the resources has the highest rank; and the one whose access to resources is limited does not enjoy the same degree of social power. The public approves the ones who possess the power and accepts the class attached to the character. After the Islamic Revolution, there were drastic changes in class rankings in Iran, those who grasped the power got promoted and those who lost power got demoted. The public agrees with those in power rather than those who are most righteous. It is an assumption that whoever has the connections and is in a position of power will be adored more than others; in this way, society' belief is shaped.

The role of class associated with power makes Persian culture a different one from the English. The reason for frequent use of the functions above is evidence to the fact that one can negotiate with the powerful addressee for a request, right, or a wish. The more unchallenged the power accumulated, the more will be signs of mitigation, swearing, etc in speech. The ultimate consequence of the process leads to the belief that the one 
with most power is the one with most respect and the one with highest class. The socialist view after the Revolution changed definition of power in the sense that a new generation without necessarily being wealthy became the elite of the society; therefore, the definitions of class which could be held for Western societies do not hold true of our culture which is highly powerdominated and publically oriented. The assumption leads us to believing that it is a part of the socio-cognitive being and nature of the Persians which decides which type of ruling system, for example, should exist; one with principle is never heard and attended to unless he has access to resources and is endorsed by the righteous religious elite. Religion plays a major part in Persian culture, this is the reason speakers make frequent use of the functions of swearing, mitigation, and the like. The list of mitigation devices is a long one, it starts from thanking words to confessing to one's humbleness to the degree of being one's slave, worshiper, hand kisser, etc. And the list goes on and on, not the mitigational expressions but also honorific verbs which show the speakers' confirmation of own inferiority and others' superiority. The history of Persian culture contains thousands of years of royal ruling; the effects are demonstrated in verbal behavior. One who is of higher position is not entitled to laugh, tell jokes, dressed informally, be close to the ordinary class, never smile, talk always seriously, have the least number of contacts with others, and hide from the public as much as possible. All these attributes are related to the socio-cognitive heritage of our historical past when kings ruled and around the kings were those who were secure only if they praised.

The ideas presented in the summary are valuable topics and issues for further research on the speech of Persian under the influence of social norms governing the style and the manner of it. Plenty of data could have been provided which would shed light on the socio-cognitive aspects of the Persian culture as manifested in speech. Suggestions could be made for directing research to the ethnographical aspects of how speech is made under the effect of numerous social effects of the variables governing Persian's social life.

The conclusion is that translating the functional effects is relative across languages in the sense that not only propositions but also idioms, referential items, swearing variations, honorific devices used in pronominal reference as well as in the inflectional endings are all among the units which could not be conveyed in English. Above all, there are synonymous verbs as well as adverbs which differ only in terms of being either honorific or non-honorific in Persian. For translating them, one has to choose equivalent units which cannot or do not carry the same level of effect.

\section{References}

Blini, L. and F. Matte Bon. 1996. "Osservazioni sui meccanismi di formazionedeisottotitoli", in C. Heiss and R.M. BollettieriBosinelli (eds.) Traduzionemultimediale per il cinema, la televisione, la scena. Bologna: Clueb, 317-332.

BussiParmiggiani, E. 2002. "Forme di attenzione e di pluricodicitànel film sottotitolato", in Caimi, A. (ed.) Cinema: Paradisodellelingue. I sottotitolinell'apprendimentolinguistico.Rassegnaltaliana di LinguisticaApplicata35(1-2): 177198.

Gottlieb, H. (1992). Subtitling- a New University discipline. In: C. Dollerup, et al. (Ed.). Teaching Translation and Interpreting. (pp. 161-70). Amsterdam: John Benjamins.

Hatim, B. and I. Mason. 2000. "Politeness in screen translating", in Venuti, L. (ed.) The Translation Studies Reader. London/New York: Routledge, 430-445.

Kovačič, I. 1996. "Subtitling strategies: A flexible hierarchy of priorities", in Heiss, C. and R.M. BollettieriBosinelli (eds.) Traduzionemultimediale per il cinema, la televisione, la scena. Bologna: Clueb, 297-305.

Newmark, P. (1988a). Approaches to Translation. London: Prentice Hall International (UK) LTD.

Newmark, P. (1988b). A Textbook of Translation. London: Prentice Hall International (UK) LTD.

O'Connell, E. (2000). Minority Language Dubbing for Children: Strategic Considerations. In: G. Jones, (Ed.). Proceeding of the Mercator Conference on Audiovisual Translation and Minority Languages. (pp. 62-72). Aberystwyth: Mercator Media.

Pavesi, M. 2002. "Sottotitoli: dallasemplificazionenellatraduzioneall'apprendimentolinguistico", in Caimi, A. (ed.) Cinema: Paradisodellelingue.I sottotitolinell'apprendimentolinguistico.Rassegnaltaliana di LinguisticaApplicata35(1-2): 127142. 